\title{
Determination of minimal age of five species of Chusquea bamboos through rhizome analysis as a tool to predict the flowering in southern Chile
}

\author{
Determinación de la edad mínima de cinco especies de Chusquea mediante el análisis \\ de rizomas como un método para predecir las floraciones en el sur de Chile
}

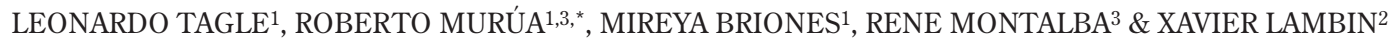 \\ ${ }^{1}$ Instituto de Ecología y Evolución, Facultad de Ciencias, Universidad Austral de Chile, Valdivia, Chile, Casilla 567 \\ ${ }^{2}$ School of Biological Sciences, University of Aberdeen, Zoology building, Aberdeen AB24 2TZ, UK \\ ${ }^{3}$ Departamento de Ciencias Agronómicas y Recursos Naturales e Instituto del Medio Ambiente, Universidad de La Frontera, \\ Casilla 54-D, Temuco, Chile \\ *Corresponding author: romuba65@gmail.com
}

\begin{abstract}
Synchronous flowering and subsequent drying up of bamboos of the genus Chusquea are important processes in the dynamics and structure of many forest ecosystems. In southern South America, bamboo flowering and subsequent mast seeding trigger rodent outbreaks associated with zoonotic diseases. Predicting future flowering events requires knowledge of the age of bamboo stands together with species-specific periodicity in flowering. We explored whether it is possible to predict the minimum age in bamboo plants based on the features of their rhizomes. We studied bamboo stands of age known by the local people in 15 sites in the coastal and Andes Mountains as well as in and the Central Valley of southern Chile ( $37^{\circ} 48^{\prime}-43^{\circ} 58^{\prime}$ S, from 12 to 1047 m.a.s.1.). For 164 individual plants, of five South American Chusquea bamboo species (C. valdiviensis, C. uliginosa, C. culeou, C. montana, and C. macrostachya), we collected and characterized the number and shape of divisions of whole rhizomes. For all species sampled there was a tight linear relationship between plant age and the number of rhizome divisions or rhizomes, accounting for 11-99 $\%$ of variation. In order to overcome constraints caused by the limited number of age cohorts available for individual species and to allow for prediction over a wider range of age, we also fitted a common linear model to species with similar age-rhizome relationships. We provide calibration relationships that can be used for retrospectively estimating the date of last flowering over large areas where bamboos form part of the understory and for predicting the future flowering events.
\end{abstract}

Key words: age determination, Bamboo, Chusquea spp., Hanta, seed masting, rhizome.

\section{RESUMEN}

La floración y posterior desecamiento de la Bambúsea del género Chusquea son procesos importantes en la dinámica y estructura de muchos ecosistemas forestales. Además, en Sudamérica desencadenan grandes tamaños de poblaciones de roedores, "ratadas," asociados con enfermedades zoonóticas. Para predecir futuros eventos de floraciones se requieren conocer la edad de los quilantos y los períodos en que ocurren. Exploramos la posibilidad de predecir la edad mínima de las plantas de quila a partir de las características de los rizomas en 5 especies de quila (C. valdiviensis, C. uliginosa, C. culeou, C. montana y C. macrostachya) de edad conocida por personas de la localidad en 15 sitios

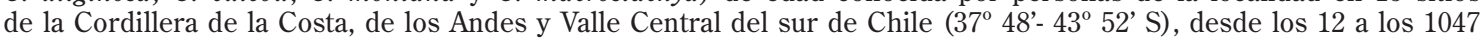
m.s.n.m. En 164 plantas individuales colectamos y caracterizamos el número y forma de las divisiones del rizoma de plantas. Para cada especie se encontró una relación linear entre la edad de la planta y el número de divisiones de rizomas o rizomas para plantas entre 6 y 42 años de edad, que dieron cuenta del 11 al $99 \%$ de la variación. Con el fin de ampliar el limitado rango de edad disponible y el rango de edad de las predicciones, se ajustó un modelo lineal común a las especies con similar relación entre edad y rizoma. La relación de las calibraciones pueden ser así utilizadas en forma retrospectiva para estimar la última fecha de floración en una gran área donde Chusquea spp. forma parte del sotobosque y para predecir futuros eventos de floraciones.

Palabras clave: Chusquea spp., determinación de edad, Hanta, rizoma, semillación. 


\section{INTRODUCTION}

Bamboo is a plant of global interest because of their distinctive life form, the major role they play in forest ecosystem dynamics (Keeley \& Bond 1999), and the wide range of uses and value they have for humans and wildlife species. Bamboos have a global distribution, ranging from $46^{\circ} \mathrm{N}$ to $47^{\circ} \mathrm{S}$ latitude, reaching elevations as high as 4000 m.a.s.l. and occurring in a wide range of ecosystems (Huberman 1959, McNeely 1996). In almost all Latin American habitats 64 bamboos from the genus Chusquea are found, which accounts for $50 \%$ of the mountain species of Andean countries (Clark 1995, Matthei 1997, Judziewicz et al. 1999). In southern South America Chusquea colonizes evergreen forests and false beech (Nothofagus spp.) dominated forests of Chile and Argentina, from sea level to 1200 m.a.s.l. (Veblen 1979). Chusquea bamboo populations of the same lineage are characterized by synchronized blooming and subsequent death, occurring after variable, but not always well-known, periods of vegetative growth (Jaksic \& Lima 2003). The Chusquea flowering phenomenon may occur over extensive geographic areas, as happened in Southern Chile during the 1990 's, with more than $10000 \mathrm{~km}^{2}$ of C. valdiviensis (E Desvanaux 1854) involved in sequential flowering from 1991 to 1993 (Pacheco 1993, González \& Donoso 1999). There are prior records of massive flowering of different Chusquea species including by Ch. uliginosa (R Philippi 1859) in 1962-1963, in 1977-1978 (Chusquea spp.) and in 2001 (C. culeou (E Desvaux 1854)) (Jaksic \& Lima 2003).

These massive flowering events by bamboos of the genus Chusquea also trigger outbreaks of rodent populations, the so-called "ratadas" recorded since 1552 (Jaksic \& Lima 2003). In southern Chile several cricetid rodents respond with outbreaks (Murúa et al. 1996, Gallardo \& Mercado1999, González et al. 2000), but one granivorous species, Oligoryzomys longicaudatus (Bennett, 1832) (OL), is epidemiologically important because it is a confirmed reservoir of a zoonotic diseases, Hantavirus (Medina et al. 2009). Outbreaks of OL seemingly, in turn, underpin variation in the prevalence of Hanta virus infections amongst humans (Toro et al. 1998).

Regeneration occurs during spring after a winter period of decomposition of dried biomass, thus beginning another period of growth and development (Huberman 1959, McClure 1966, Janzen 1976, Sharma 1982, Franklin 2004). The plants of Chusquea are formed by an aerial part (culms, twigs and leaves) and a subterranean part (rhizome). The rhizomes are modified stems that support the aerial stems, storing foods and functioning as vegetative reproductive organs in woody bamboos. They are formed by repeated units including nodes, internodes, bud and roots (Hidalgo 2003). The rhizome of southern South American Chusquea are pachymorphic, with strong, thick and short ramified rhizomes, 5 to $15 \mathrm{~cm}$ long, each splitting in two or three new rhizomes every spring (Pearson et al. 1994, Watanabe et al. 1996, 1997). New rhizomes produce roots and culms yearly until they senesce. We hypothesized that the patterns of growth and division of rhizome would be related to the age of the plants.

Bamboo plants play an important ecological role fostering the regeneration of shadeintolerant species, such as Fagus in Japan (Abe et al. 2001), Abies and Betula spp. in south-western China (Taylor et al. 2004) and Nothofagus spp. in South America (Veblen 1979, Holtz \& Veblen 2005). Forest disturbances affect light availability in the shrubs strata modifying germination and growth of other species (Valeria 1996). Also, the thick covering of the ground surface with dead leaves following a flowering event may affect the germination of understory plants (González \& Donoso 1999).

Here we report on an investigation that combines knowledge of the growth pattern of Chusquea rhizomes and detailed examination of plants of known age in order to calibrate relationships that could be used to predict the likelihood of future flowering events and possibly the so called "ratadas" with the associated public health consequences.

\section{METHODS}

We selected 15 sites, distributed between $37^{\circ} 30^{\prime}$ and $43^{\circ} 50^{\prime} \mathrm{S}$ in both the coastal and Andes cordilleras and central valley of southern Chile which included 5 species of Chusquea (C. valdiviensis, C. uliginosa, C. culeou, C. montana (R Philppi 1864) and C. macrostachya (R Philppi 1864)). Samples were collected from January 2004 to March 2006. Individual plants of known age were selected by interviewing local people who witnessed the last flowering events and subsequent regeneration. The maximum age of individual plants was determined by 


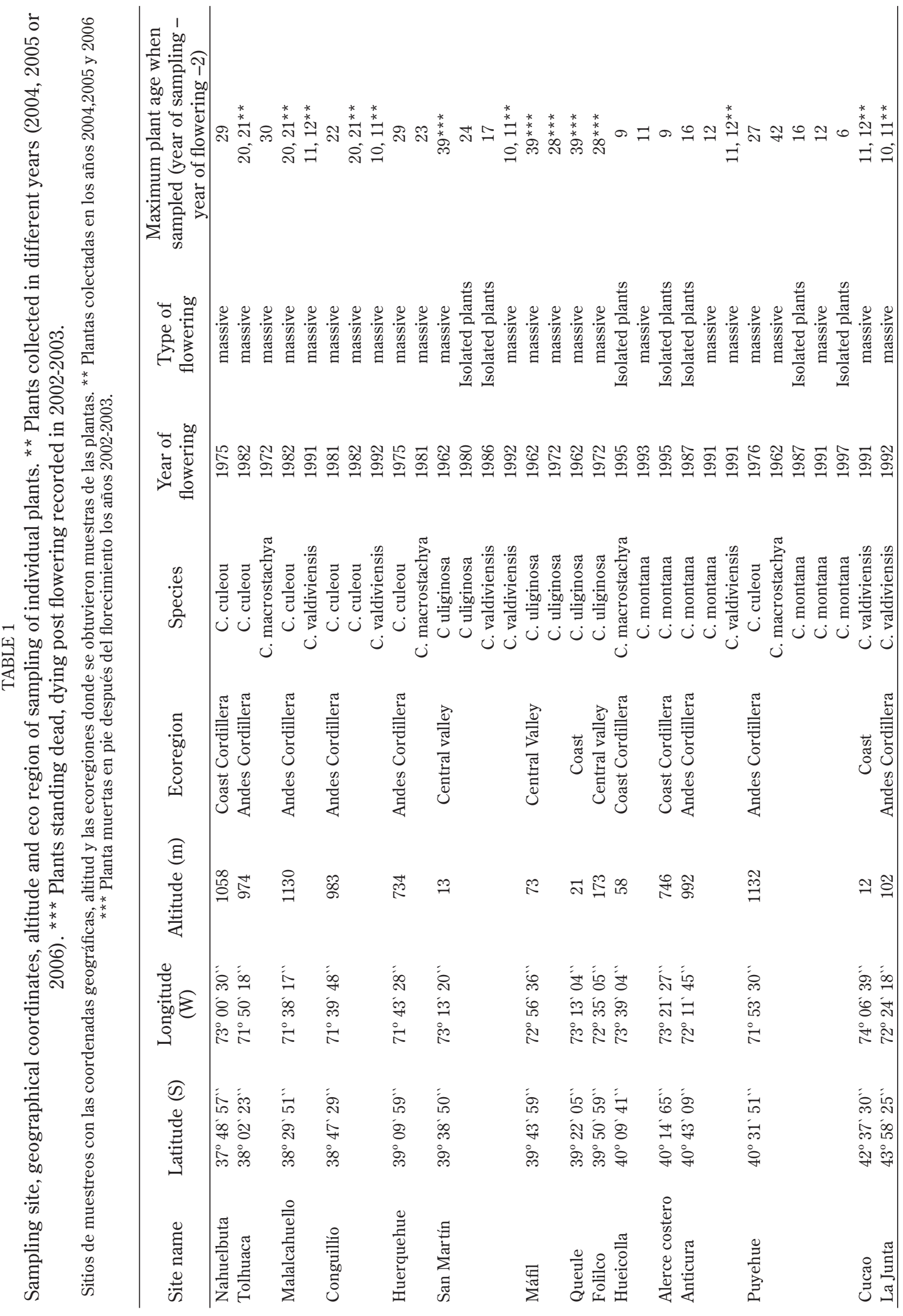


subtracting 2 years from the flowering date of parent plants (González \& Donoso 1999). Details of the sites studied are shown in Table 1.

One hundred and sixty four complete rhizomes, some larger than $3 \mathrm{~m}^{3}$, were excavated. Rhizomes were cut and cleaned in the laboratory. The shape, growth form, number of rizhomes, number of splitting events and the structure of the rhizomes were recorded (Figure 1). The older rhizome were identified and considered the starting point of a branching process, and each rhizome and splitting events were marked with different colored pins. Figure 1 shows details of a Chusquea plant and details of the propagation and the divisions in the rhizome underground.

(A)

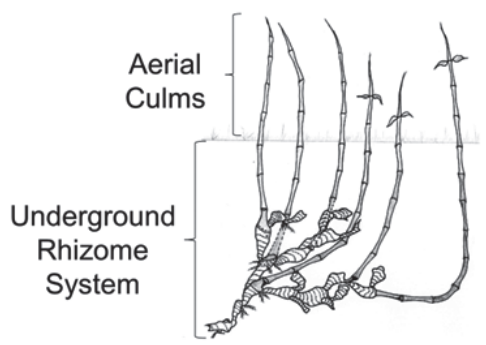

(B)

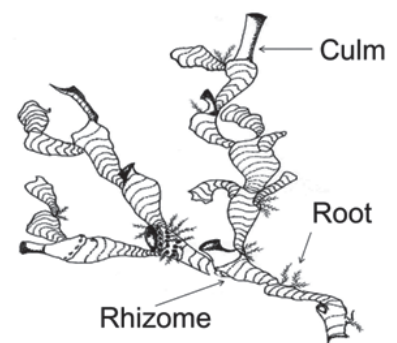

(C)

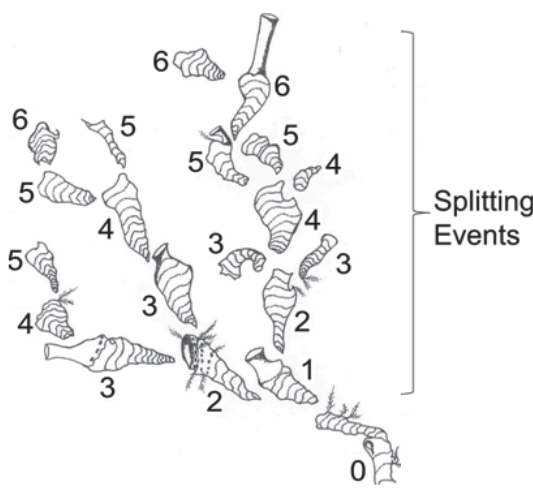

Fig. 1: Details of a Chusquea spp. A and B show the structure of Chusquea plant and its rhizome. C shows details of the pattern of splitting events and the rhizome divisions. The numbers refer to the sequence of splitting events, starting from the root (numbered 0 ).

Detalles de la planta Chusquea spp. A y B muestran la estructura de una planta Chusquea y su rizoma. Figura C muestra detalles del patrón de eventos de separación y las divisiones del rizoma. Los números se refieren a la secuencia los eventos de separación comenzando desde la raíz (identificada con el número 0).
Generalized linear models with a Gaussian error and identity link were fitted with age as dependent variable and the number of splitting events and rhizomes as predictors. Common models for all species (with species as covariates) were fitted, as well as single species models to overcome the limited range of age classes sampled for each species. GLMs were fitted using S-Plus 6.1 (Insightful Corp.). All means are reported with their standard error.

\section{RESULTS}

In twenty two samples out of 33 , we were able to sample bamboos from one species from a single age cohort, whereas in nine sample sites, two age cohorts of a species were sampled. This reflects both the availability of plants of known age as well as the likely dominance of one or more age cohorts at each site. Bamboo plant age, according to local witnesses, ranged from 6 to 42 years old and resulted from either massive flowering or of flowering by isolated plants (Table 1). Simple linear regressions with the number of splitting events as a linear predictor of age were significant for all species and explained $78-98 \%$ of variance in age $(C$. culeou: $\left.\mathrm{F}_{2,34}=118.7 ; \mathrm{P}<0.001\right) ;$ C. macrostachya: $\mathrm{F}_{2,28}=1210, \mathrm{P}<0.001 ;$ C. montana: $\mathrm{F}_{2,34}=189.3$, $\mathrm{P}<0.001$; C. uliginosa: $\mathrm{F}_{2,17}=897.3, \mathrm{P}<0.001$; C. valdiviensis $\mathrm{F}_{2,41}=184.2, \mathrm{P}<0.001$ ) (Table 2). Whereas intercept estimates fluctuated widely and values were not biologically meaningful, reflecting our use of linear models and the paucity of data at low age. Estimates of the number of splitting events per year (slopes) were rather consistent, ranging from 0.85 to 1.27, except for Ch. uliginosa that had a low estimate of 0.62 .

Simple linear regressions using the number of rhizomes as a linear predictor of age were also significant, although with lower coefficient of determination than for the number of splitting events, (C.culeou $\mathrm{F}_{2,34}=8.248, \mathrm{P}<$ $0.001 ;$ C. macrostachya $\mathrm{F}_{2,28}=164.5, \mathrm{P}<0.001$; C. montana $\mathrm{F}_{2,34}=24.7, \mathrm{P}<0.001 ;$ C. uliginosa $\mathrm{F}_{2,17}=276.5, \mathrm{P}<0.001$, C. valdiviensis $\mathrm{F}_{2,41}$ $=4.85, \mathrm{P}<0.03)$. Even though the natural logarithm of the number of rhizome should better reflect the multiplicative nature of the rhizome multiplication process, models predicting age based on natural logarithm of number of rhizome only improved fit relative to untransformed values for one of 5 species (C. uliginosa $\mathrm{F}_{2,17}=276.5, \mathrm{P}<0.001, \mathrm{R}^{2}=0.94$ ). The best linear regression for this species was 
TABLE 2

Parameters (standard errors) and coefficient of determination of Chusquea species specific linear regressions predicting plant age with the number of splitting events and numbers of rhizomes to estimate age by each one of the five species of Chusquea. The regressions were not forced through the origin.

Parámetros (error estándar) y coeficientes de determinación de las regresiones especie específicas de Chusquea para estimar la edad de la planta, el número de eventos de separación ocurridos y el número de rizomas en las cinco especies de Chusquea. Las regresiones no se forzaron a pasar por el origen.

\begin{tabular}{|c|c|c|c|c|}
\hline \multirow{2}{*}{ Species } & \multirow{2}{*}{$\begin{array}{l}\text { Splitting events } \\
\text { Equation }\end{array}$} & \multicolumn{3}{|c|}{ Rhizomes } \\
\hline & & $\mathrm{R}^{2}$ & Equation & $\mathrm{R}^{2}$ \\
\hline $\begin{array}{l}\text { C. culeou } \\
\mathrm{n}=36\end{array}$ & $\begin{array}{c}\text { age } \sim 2.12(2.49)+1.27(0.12)^{*} \\
\text { splitting event }\end{array}$ & 0.78 & $\begin{array}{c}\text { age } \sim 0.14(0.37)+ \\
1.03(0.02)^{\star} \text { rhizomes }\end{array}$ & 0.39 \\
\hline $\begin{array}{l}\text { C. macrostachya } \\
\mathrm{n}=30\end{array}$ & $\begin{array}{l}\text { age } \sim 2.18(0.91)+1.07(0.03)^{*} \\
\text { splitting event }\end{array}$ & 0.98 & $\begin{array}{l}\text { age } \sim 2.43(2.43)+ \\
0.68(0.05)^{\star} \text { rhizomes }\end{array}$ & 0.85 \\
\hline $\begin{array}{l}\text { C. montana } \\
\mathrm{n}=36\end{array}$ & $\begin{array}{c}\text { age } \sim 3.23(0.7)+0.96(0.07)^{*} \\
\text { splitting event }\end{array}$ & 0.85 & $\begin{array}{l}\text { age 3.77(1.79) + } \\
0.46(0.09)^{*} \text { rhizomes }\end{array}$ & 0.42 \\
\hline $\begin{array}{l}\text { C. uliginosa } \\
\mathrm{n}=19\end{array}$ & $\begin{array}{c}\text { age } \sim 16.52(0.6)+0.62(0.02)^{*} \\
\text { splitting event }\end{array}$ & 0.98 & $\begin{array}{l}\text { age 22.5(0.73)+ } \\
0.13(0.01)^{\star} \text { rhizomes }\end{array}$ & 0.92 \\
\hline $\begin{array}{l}\text { C. valdiviensis } \\
\mathrm{n}=43\end{array}$ & $\begin{array}{c}\text { age } \sim 2.64(0.64)+0.85(0.06)^{*} \\
\text { splitting event }\end{array}$ & 0.82 & $\begin{array}{c}\text { age } \sim 8.91(1.02)+ \\
0.125(0.06)^{\star} \text { rhizomes }\end{array}$ & 0.11 \\
\hline
\end{tabular}

TABLE 3

Parameter estimates of General linear Models considering the number of splitting events as predictor of age in five species of Chusquea.

Parámetros estimados del Modelo Lineal Generalizado considerando el número de eventos de separación ocurridos como predictor de edad en las cinco especies de Chusquea.

\begin{tabular}{lccc}
\hline Age Propagations & Coefficient & Standard Error & P-value \\
\hline Intercept & 4.49 & 0.51 & 0.000 \\
splitting events & 0.95 & 0.03 & 0.000 \\
C. culeou & 2.15 & 0.99 & 0.031 \\
C. macrostachya & 1.07 & 0.43 & 0.014 \\
C. montana & 3.85 & 0.29 & 0.000 \\
C. uliginosa & -0.46 & 0.23 & 0.047 \\
splitting event * C. culeou & -0.1 & 0.04 & 0.026 \\
splitting event * C. macrostachya & -0.07 & 0.03 & 0.035 \\
splitting event * C. montana & -0.12 & 0.013 & 0.000 \\
splitting event * C. uliginosa & -0.024 & 0.02 & 0.238 \\
\hline
\end{tabular}

thus: age $~ 2.05(1.92)+7.46(0.45) * \ln$ (rhizomes). Figures $2 \mathrm{a}$ to $2 \mathrm{e}$ shows linear regression for each species. The fit of the linear regression for $C$. valdiviensis was poor, even if significant, when using number of rhizomes as predictor of age.

In order to overcome the limited age range available for individual species and to widen the range of age predictions for species with similar age-rhizome relationships, we also fitted GLM (analysis of covariance), with species identity as factor and splitting events as linear predictor of age. The model was highly significant $\left(\mathrm{F}_{2,154}=\right.$ 9743; $\mathrm{P}<0.00001$ ) and accounted for $98 \%$ of the variance in age (null deviance: 19108.65 on 163 


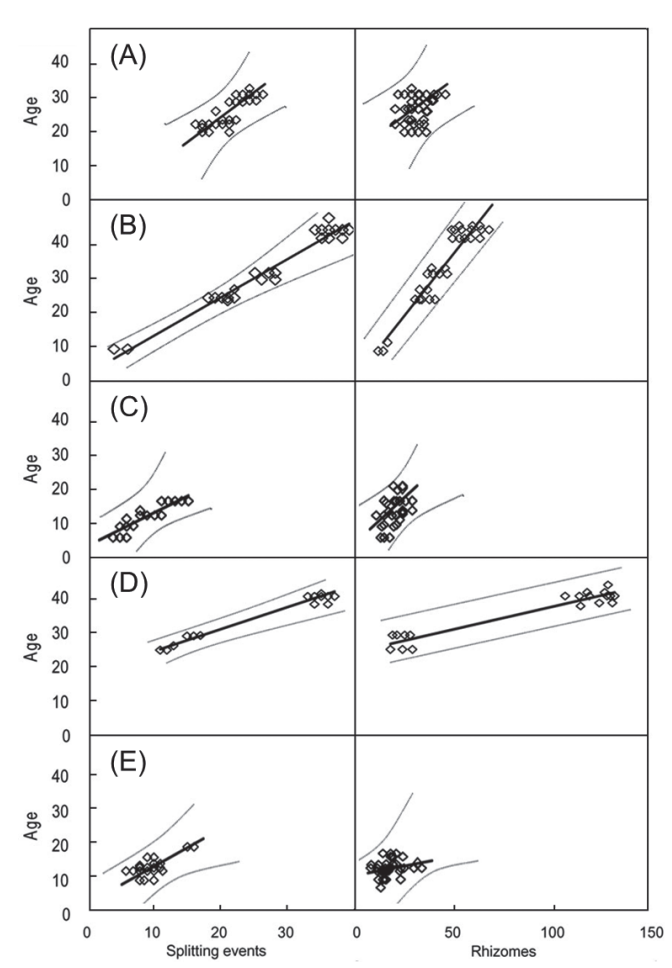

Fig. 2: Single regression for five species of Chusquea using splitting events and rhizomes to predict age. A C. culeou, B C. macrostachya, C C. montana, D C. Uliginosa, E C. valdiviensis.

Regresiones simples para predecir la edad usando los eventos de separación y rizoma en cinco especies de Chusquea. A, C. culeou, B, C. macrostachya, C, C. montana, D, C. uliginosa E $C$ valdiviensis. df, residual deviance: 287.99 on 154 df). There was statistical support for different intercepts $\left(\mathrm{F}_{5,154}=46.3, \mathrm{P}<0.00001\right)$ and different slopes (interaction splitting event ${ }^{\star}$ species $\mathrm{F}_{10,154}=$ $36.6, \mathrm{P}<0.0001)$. We found no support for a common slope for $C$. valdiviensis and $C$. uliginosa when we fitted an ANCOVA model for those two species $\left(\mathrm{F}_{1,58}=12.82, \mathrm{P}=0.0007\right)$. On the other hand, a model for the other three species (C. culeou, C. macrostachya and $C$. montana) gave support for common slopes $\left(\mathrm{F}_{2,98}=0.083, \mathrm{P}=0.92\right)$ and intercepts $\left(\mathrm{F}_{2,96}\right.$ $=2.53, \mathrm{P}=0.085)$. Thus a common linear regression, accounting for $97.6 \%$ of variance for those three species is Age $\sim 2.21(0.35)+$ $1.064(0.016){ }^{*}$ splitting event (Fig. 3).

A similar GLM with rhizome as linear predictor was also significant $\left(\mathrm{F}_{2,162}=1284\right.$, $\mathrm{P}<0.00001$ ), accounting for $95.3 \%$ of the variance in age significant variation in different intercepts and slopes between species $\left(\mathrm{F}_{5,162}\right.$ $\left.=148.5, \mathrm{P}<0.00001 ; \mathrm{F}_{10,162}=53.9, \mathrm{P}<0.0001\right)$ respectively. The difference in slopes here stemmed from $C$. valdiviensis producing more rhizomes per year than C. culeou, C. montana, C. macrostachya and C. uliginosa.

C. valdiviensis and $C$. uliginosa had undistinguishable slopes $\left(\mathrm{F}_{1,58}=0.000, \mathrm{P}=\right.$ 0.996), but different intercept. The model for C. valdiviensis was: Age (15.7(0.51)-6.8(0.39)

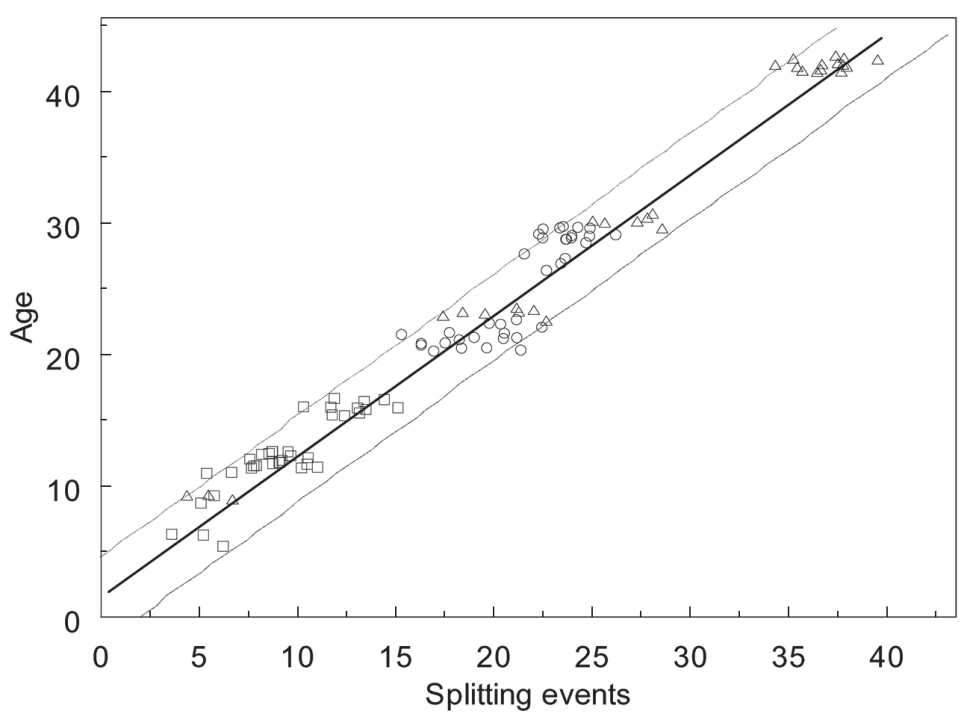

Fig. 3: Common regression for C. culeou ( $\square), C$. macrostachya $(\Delta)$ and $C$. montana $(\circ)$ using the number of splitting events as predictor of age.

Regresión usando los eventos de separación como predictor de la edad en C. culeou ( $\square)$, C. macrostachya ( $\Delta$ ) y C. montana (॰). 
TABLE 4

General linear Models considering number of rhizomes to estimate age in five species of Chusquea.

Parámetros del Modelo lineal Generalizado considerando los rizomas para estimar la edad en cinco especies de Chusquea.

\begin{tabular}{lccc}
\hline Age Rhizomes & Coefficient & Standard Error & P-value \\
\hline Intercept & 7.55 & 0.78 & 0.000 \\
Rhizome & 0.48 & 0.03 & 0.000 \\
C. culeou & 1.14 & 1.48 & 0.441 \\
C. macrostachya & 0.83 & 0.81 & 0.307 \\
C. montana & 5.09 & 0.41 & 0.000 \\
C. uliginosa & -0.34 & 0.32 & 0.282 \\
Rhizome * C. culeou & -0.18 & 0.06 & 0.002 \\
Rhizome * C. macrostachya & -0.13 & 0.04 & 0.007 \\
Rhizome * C. montana & -0.14 & 0.01 & 0.000 \\
Rhizome * C. uliginosa & -0.08 & 0.02 & 0.000 \\
\hline
\end{tabular}

$+0.13(0.01)^{*}$ rhizomes and for C. uliginosa: Age $\sim 15.7(0.51)+0.13(0.01) *$ rhizomes $\left(\mathrm{R}^{2}=\right.$ 0.974). Finally, a GLM including the 3 other species (C. culeou, C. macrostachya and $C$. montana $)$ had species-specific slopes $\left(\mathrm{F}_{2,98}=\right.$ 103.4, $\mathrm{P}<0.000)$ and intercepts $\left(\mathrm{F}_{2,96}=6.13, \mathrm{P}\right.$ $=0.003)$.

\section{DISCUSSION}

We found that simple linear model gave an often excellent fit to the relationship between the age of Chusquea bamboo plants aged 5 to 50 years and the number of splitting events or rhizomes. This was made possible by our

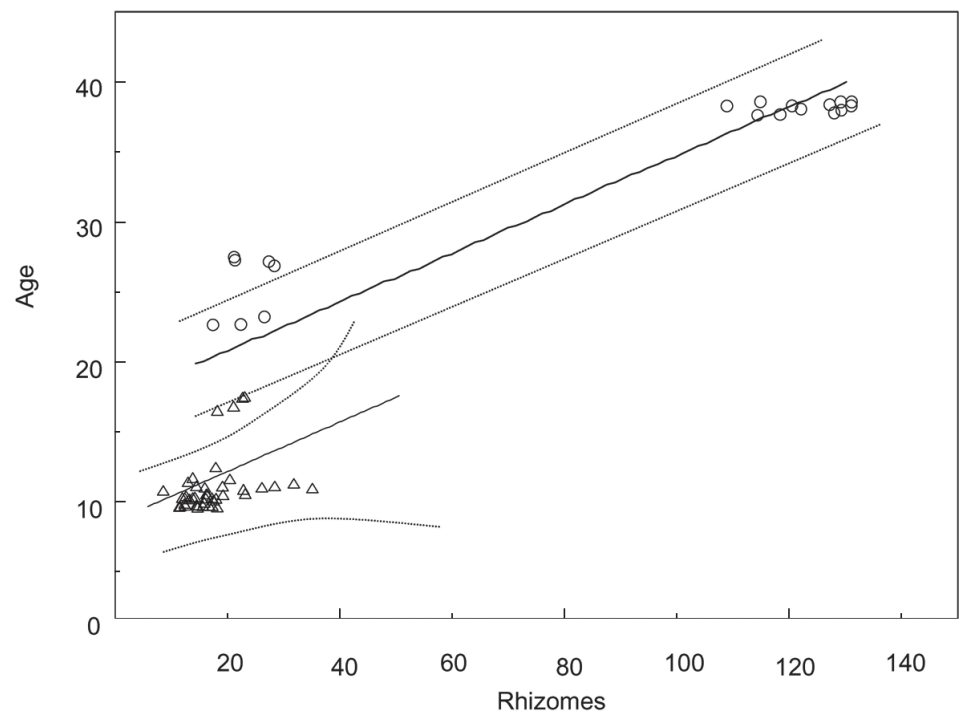

Fig. 4: Common regression for $C$. uliginosa $(\circ)$ and $C$. valdiviensis $(\Delta)$ using the number of rhizomes as predictor of age. 
use of local knowledge of individual plants by the local inhabitants we interviewed. Overall, a linear relationship between plant age and the number of splitting events provided a superior predictive ability than a relationship involving the number of rhizomes. A log linear relationship expected from the multiplicative nature of the rhizome expansion process only gave a better fit than a linear model for $C$. uliginosa. This would suggest that rhizomes of this species senesce more slowly than those of other species.

Despite our large scale sampling effort, each species was represented by one or two, always adjacent, cohorts at each site and by a small number of cohorts throughout our sampling area. For $C$. valdiviensis in particular, the overall range of age encountered was small, and this greatly reduces the predictive power of the relationships for this species. As our intent was to produce a pragmatic relationship that could be used for predicting future bamboo flowering events and the associated Hanta virus epizootic risk to humans, we chose to overcome this constraint inherent to the biology of the species by deriving common relationships for bamboo species that had similar growth patterns. Here, we found that $C$. culeou, C. macrostachya and $C$. montana had similar growth rates for both propagation and rhizomes, and $C$. uliginosa and $C$. valdiviensis seemingly have similar growth rates, lower than those of the other three species considered. Clearly, given the limited age range available for $C$. valdiviensis, any inference and estimation of age from root structure should be made with caution.

While we are well aware that bamboos do not grow linearly, we deliberately restricted ourselves to linear relationships that gave more than satisfactory fit over the range of ages considered. Fitting more biologically realistic non-linear growth curves must await more data on growth patterns in the early years of growth. Thus, while the intercept of the relationships derived have no biological meaning, the estimated growth rate of one propagation per year has useful practical applications. The overall linear regression can be used for estimating plant age in an area. Indeed, Chusquea bamboo flowering is followed by massive seed production and this notoriously triggers outbreaks of the Sigmodontinae reservoir of the Andes Hanta virus, Oligoryzomys longicaudatus (González et al. 1989, Murúa \& Padula 2004, Murúa \& Briones 2005 ) with Hantavirus prevalence on both side of the Andes Mountains (Murua et al. 2003, Piudo et al. 2005). There is a clear public health need to predict the likely occurrence of these outbreaks, and excavation of bamboo plants in a 241 wide range of area could provide a useful indicator of the flowering probability.

Even though our sampling scheme was not random with respect to the age of plants (indeed, we only sampled plants that were known by local residents), the fact that we only encountered one or, at most two, age cohorts at a given site is strongly indicative that the age structure of bamboo is uni-modal, such that a surveillance program based on even a limited sampling effort at each location would yield highly valuable information on bamboo age structure. Furthermore, once implemented, such surveillance effort would not have to be repeated and would yield critical information on the size of areas with similar bamboo age structure and thus likely to be affected synchronously by a rice rat outbreak.

While knowing the age of bamboo plants would be most useful as a public health tool, in conjunction with precise knowledge of the age at flowering of each bamboo plant, the available information on the age of bamboo at flowering is not un-ambiguous and free of controversy (Jaksic \& Lima 2003). Specifically, it is not absolutely clear whether each bamboo species has a fixed flowering age or whether a deterministic ontogenic component to the probability of flowering is modified by environmental conditions. The interval between flowering events has been reported as 61 years for a given $C$. culeou southern Argentinean population and as 50 to 70 years for $C$. valdiviensis for a population in southern Chile (González \& Donoso 1999). However, for most bamboo species worldwide, neither the age nor any environmental trigger of flowering is well-known (Clark 1995, Bystriakova et al. 2004). In most cases, the information available in the literature often goes no further than reporting the intervals between flowering events in an area, without explicit reference to the interval between flowering of plants and their progeny. For instance, while Jaksic \& Lima (2003) concluded from their review that $C$. culeou flowers every 14 years, we encountered 
numerous plants that were 20-29 years old. It is thus important to clearly specify the spatial scale considered, as well as ensuring the same population actually flowered repeatedly when reporting flowering intervals. Clearly, there is a need to obtain more information on the determinants of bamboo masting strategies. Even in the absence of such information, the presence of cohorts of bamboo that are 30-40 years old (C. uliginosa and C. macrostachya) must be at least indicative of heightened risk for areas where those species prevail. Indeed, the probability of flowering certainly increases with age. We observed a relationship between the ages recorded by processing the rhizomes in all the species and past flowering recorded by several authors previously (Veblen 1982, Veblen \& Schlegel 1982, Veblen et al. 1979, Pacheco 1993, Schlegel 1993, Pearson 1994, Valeria 1996, Jaksic \& Lima 2003). There were four cohorts that could be linked to massive flowering events (C. uliginosa and C. macrostachya: 1962-1964; C. uliginosa, C. macrostachya and C. culeou: $1972-1976$ and $1980-1982$ and Ch. valdiviensis and C. montana: $1991-1995)$ and two cohorts that could be traced back to isolated plants flowering (C. valdiviensis and C. montana: 1986 -1987 and C. montana 1997) (Table 1). None of the sampled plants seemed to be part of the flowering event of 1977-1978 (Murúa et al. 1986, Anonymous 1994, González \& Donoso 1999, cited in Jaksic \& Lima 2003).

ACKNOWLEDGEMENTS: This work was funded by a The Wellcome Trust/ Grant 070461 to Xavier Lambin and Roberto Murúa. We thank the many park rangers and local farmers who kindly informed us of the date of bamboo flowering in their area and of the age of the specific plants we sampled. We are also grateful to Pedro Muñoz, San Martin park keeper for his assistance in field work and Lautaro Bahamondes for the illustration. Revista Chilena de Historia Natural has a publishing policy by which full articles are available for free in line up with the Wellcome Trust Grant procedures.

\section{LITERATURE CITED}

ABE M, H MIGUCHI \& T NAKASHIZUKA (2001) An interactive effect of simultaneous dead of dwarf bamboo, canopy gap, beach regeneration. Oecologia 127: 281-286.

BYSTRIAKOVA N, V KAPOS \& I LYSENKO (2004) Bamboo biodiversity. UNEP-WCMC/INBAR, USA.

CLARK L (1995) Diversity and distribution of andean woody bamboos. In: Churchill SP, H Balsley, E Forero \& JL Luteyin (eds) Biodiversity and conservation of neotropical montane forests: 501512. New York Botanical Garden, New York USA.

FRANKLIN D (2004) Synchrony and asynchrony: observations and hypotheses for the flowering wave in a long-lived semelparous bamboo. Journal of Biogeography 31: 773 .

GALLARDO M \& C MERCADO (1999) Mast seeding of bamboo shrubs and mouse outbreaks in Southern Chile. Mastozoología Neotropical (Argentina) 6: 103-111.

GONZÁLEZ M \& DONOSO C (1999) Producción de semillas y hojarasca en Chusquea quila (Poaceae: Bambusoideae), posterior a su floración sincrónica en la zona centro-sur de Chile. Revista Chilena de Historia Natural 72: 169-180.

GONZÁLEZ L, R MURÚA \& C JOFRÉ (1989) The effect of seed availability on population density of Orizomys in Southern Chile. Journal of Mammalogy 70:401-403.

GONZÁLEZ L, MURÚA R \& C JOFRÉ (2000) Habitat utilization of two muroid species in relation to population outbreaks in southern temperate forests of Chile. Revista Chilena de Historia Natural 73: 489-495.

HIDALGO O (2003) Bamboo: The gift of the God. Kindle Amazon Inc. Columbia (USA)

HOLTZ A \& T T VEBLEN (2005) Tree regeneration responses to Chusquea montana bamboo die-off in a subalpine Nothofagus forest in the southern andes. Journal of Vegetation Science 17:19-28.

HUBERMAN M (1959) Bamboo silviculture. Unasylva, U. Nations (USA) 13: 36-43.

JAKSIC F \& M LIMA (2003) Myths and facts on ratadas: Bamboo blooms, rainfall peaks and rodent outbreaks in South America. Austral Ecology 28: 227-236

JANZEN D H (1976) Why bamboos wait so long to flower. Annual Review of Ecology and Systematics 7: $347-391$.

JUDZIEWICZ E J, L G CLARK, X LONDOÑO \& M J STERN (1999) American bamboos. Smithsonian Institution, Press, Washington DC.

KEELEY J \& W BOND (1999) Mast flowering and semelparity in bamboos: the bamboo fire cycle hypothesis. The American Naturalist 154: 383-391.

MATTHEI O (1997) Las especies del Género Chusquea Kunth (Poaceae: Bambusoidae), que crecen en la X región, Chile. Gayana Botanica 54: 199-220.

MCCLURE F A (1966) The bamboos, a fresh perspective. Harvard University Press, Cambridge, UK.

MCNEELY J A (1996) Bamboo, biodiversity and conservation in Asia. In: Ramanatha RV \& RIV Ramanuja (eds) Biodiversity and genetic conservation: 6-19. New Delhi, India.

MURUA R \& P PADULA (2004) Ecology and evolution of hantavirus in the Southern Cone of America. Archivos de Medicina Veterinaria (Chile) 36: 1-20.

MURÚA R \& M BRIONES (2005) Abundance of the sigmodont mouse Oligoryzomys longicaudatus and patterns of tree seeding in Chilean temperate forest. Mammalian Biology 70: 321-325.

MURÚA R, M NAVARRETE, R CADIZ, R FIGUEROA, P PADULA et al. (2003) Hantavirus pulmonary syndrome: current situation among rodent reservoirs and human population in the 10th Region. Revista Médica de Chile 131: 169-176.

MURÚA R, L GONZÁLEZ, M GONZÁLEZ \& C JOFRÉ (1996) Efectos del florecimiento del arbusto Chusquea quila Kunth (Poaceae) sobre 
la demografía de poblaciones de roedores de los bosques templados fríos del sur chileno. Boletín Sociedad de Biología de Concepción (Chile) 67: $37-42$.

PACHECO N (1993) Floración de las quilas. Flora fauna áreas silvestres FAO-PNUMA (Italia) 17: 34-35.

PEARSON A, O PEARSON \& I GOMEZ (1994) Biology of the bamboo Chusquea coleou (Poaceae: Bambusoideae) in southern Argentina. Vegetatio 111: $93-126$

PIUDO L,M MONTEVERDE,S GONZÁLEZ-CAPRIA,P PADULA \& P CARMANCHAHI (2005) Distribution and abundance of sigmodontine rodents in relation to hantavirus in Neuquen, Argentina. Journal of Vector Ecology 30:119-125.

SHARMA Y (1982) Some aspects of bamboos in Asia and the Pacific. Food and Agriculture Organization, Bangkok, Thailand.

SCHLEGEL F (1993) Quila: el problema de la floración. Chile Forestal (Chile) 206: 35-37.

TAYLOR A J Y HUANG Z S QUIANG (2004) Canopy tree development and underground bamboo dynamics in old growth Abies-Betula forest in southwestern China: a 12-year study. Forest Ecology and Management 200: 345-360

TORO J J, A VEGA, S KHAN, J N MILLS, P PADULA et al. (1998) An outbreak of hantavirus pulmonary syndrome, Chile. Emerging Infection Diseases 4: 687-694.

Editorial responsibility: Luis J. Corcuera

Received August 18, 2011; accepted May 15, 2013
VALERIA L (1996) Influencia de la floración sincrónica de Chusquea quila (Kunth) y de condiciones microclimáticas asociadas, en la dinámica regenerativa de bosques remanentes originales en la provincia de Valdivia, Tesis Ingeniero Forestal. Facultad de Ingeniería Forestal, Universidad Austral de Chile, Valdivia.

VEBLEN T T (1979) Structure and dynamics of Nothofagus forests near timberline in SouthCentral Chile. Ecology 60: 937-945.

VEBLEN T, S SCHLEGEL \& R ESCOBAR (1979) Biomasa y producción primaria de Chusquea culeou Desv, y Chusquea tenuiflora Phil, en el sur de Chile, Bosque 3: 47-56.

VEBLEN T \& F SCHLEGEL (1982) Reseña ecológica de los bosques del sur de Chile. Bosque 4: 73-116

VEBLEN T T (1982) Growth patterns of Chusquea bamboos in the understory of Chilean Nothofagus forests and their influence in forest dynamics. Bulletin Torrey Botany Club (USA) 109: 474-487

WATANABE M A ZUNINO G KAHLER \& C QUEZADA (1996). Ecological characteristics of Chusquea quila Kunth from Central-South Chile. INFOR (Chile) 94: 25-26.

WATANABE M A ZUNINO G KAHLER \& C QUEZADA (1997) Ecological characteristics of Chusquea quila Kunth from Central-South Chile. Bamboo Journal (Japan) 14: 01-14. 